\title{
Laboratory study of disturbance in marine sediments: response of a microbial community
}

\author{
Robert H. Findlay*, Melanie B. Trexler, James B. Guckert**, David C. White** \\ Department of Biological Sciences, Florida State University, Tallahassee, Florida 32306, USA
}

\begin{abstract}
Disturbance has been shown to be an important component of the ecology of soft-bottom macrobenthic and meiobenthic marine communities. Its importance in the ecology of microbial communities was investigated by using sieving of marine sediments as a controlled disturbance. Following the disturbance, sediments were maintained in microcosms. Using a suite of biochemical measures, sieving was found to influence microbial biomass, community structure, and metabolic activity. Sieving caused an immediate decrease in microbial growth rates and a shift in metabolic status towards the synthesis of phospholipid. Microbial biomass was initially unaffected. Several hours later, growth rates increased and biomass had decreased by $75 \%$. Microbial biomass returned to pre-disturbance levels $8 \mathrm{~h}$ after sieving. Groups of phospholipid, ester-linked fatty acids, each associated with different functional groups of microorganisms, varied in their response to sieving. This result suggested that components of the microbial community differed in their reaction to this disturbance. Ambient sediments collected at the time of the construction of the microcosms were contrasted with sediments maintained in the laboratory microcosms for $5 \mathrm{~d}$. Laboratory conditions significantly altered the microbial community structure and growth rates were significantly lower. Measures of metabolic status indicated that some of the microorganisms were stressed. This study demonstrates the potential significance of disturbance in the ecology of the benthic microbial community and that uncoupling sediment from the biotic and abiotic influences of the environment significantly affects the composition and activity of the microbial community.
\end{abstract}

\section{INTRODUCTION}

Sedimentary bacteria live in a physically and chemically complex environment and numerous factors have been shown to influence their distribution. Microscopic analysis indicates that marine sediments are a heterogeneous environment of organic and inorganic particles of various sizes, bridged, or encompassed, by an organic matrix (Frankel \& Mead 1973, Watling 1988). Sediment grain size, the mineral nature of the grains, and the microtopography of the grains have been shown to influence the bacterial biomass in marine sediments (Meadows \& Anderson 1967, Dale 1974, Weise \& Rheinheimer 1978, Nickels et al. 1981, DeFlaun \& Mayer 1983). In shallow waters, deposition

\footnotetext{
Present addresses:

- Darling Marine Center and Department of Microbiology, University of Maine, Walpole, Maine 04573, USA

- Institute for Applied Microbiology, University of Tennessee, Knoxville, Tennessee 37932-2596, USA
}

rates of detrital carbon are high and the majority of the decomposition of detritus occurs in the sediments (Suess 1976). The major, early diagenetic reactions result from microbiological decomposition of organic matter (Berner 1976), and this activity produces many complex gradients within the sediments which in turn affect the distribution and metabolic activities of the bacteria there (Jones 1979).

Most, but not all, marine sediments are inhabited by macrobenthos and their activities profoundly affect the physical and chemical nature of the sediments. Burrowing for shelter or food and ingestion of sediment disturbances caused by biological agents and henceforth referred to as biotic disturbance - cause changes in the grain size, sorting, fabric, water content and compaction of the sediments (for reviews see Gray 1974, Rhoads 1974, Aller 1978, Rhoads \& Boyer 1982). Biotic disturbance also affects diagenetic reactions and the porewater profiles of reactants and products (Aller 1982). Sandy sediments may have very high rates of biotic disturbance with turnover rates of 0.7 to $4 \mathrm{~d}$ for 
the top $1 \mathrm{~cm}$ of sediment (Meyer 1977). While several studies have examined the effects of tubes and burrows of infauna on microbial activity and biomass (e.g. Aller \& Yingst 1985, Dobbs \& Guckert 1988a), few have directly examined the short-term (hours) effects of biotic disturbance (e.g. Findlay et al. 1985). Findlay et al. (1985) suggested that disturbance of marine sediments would, in a matter of hours, induce significant changes in the microbial community. To demonstrate the potential of disturbance as an important controlling factor in structuring microbial communities in sediments we have employed a laboratory microcosm experimental design within which sieving serves as a controlled disturbance. We choose sieving as a controlled disturbance to simulate the disturbance caused by biotic agents that translocate large amounts of sediments (e.g. feeding rays).

An additional objective of this study was to document the changes induced in the microbial community by construction and maintenance of laboratory microcosms. Sieving of marine sediments is a common practice in construction of sediment microcosms (e.g. Findlay \& White 1983a, Aller \& Yingst 1985). The use of microcosms has become increasingly important to the study of microbial ecology as it allows a measure of control unattainable in the environment (Pritchard \& Bourquin 1984). However, several studies have suggested that important changes can occur in the microbial community of sediments maintained in microcosms (Reichgott \& Stevenson 1978, Findlay \& White 1983a, Sayler et al. 1983, Federle et al. 1986).

Toward these ends, we used an integrated biochemical approach for the measurement of microbial biomass and rates of growth. The application of these techniques has been reviewed by White $(1983,1986)$. These techniques are based on measurement of the chemical components of microbial cells. They allow assessment of microbial biomass, community structure, rates of growth, and short- and long-term metabolic status without the problems associated with direct enumeration or culture methods (White 1986). A functionalgroup analysis, a technique successfully applied in a variety of ecological studies, was used to interpret changes in microbial community structure (e.g. Steneck \& Watling 1982, Dobbs \& Guckert 1988a). These techniques were used to compare estuarine sediments to those sieved and maintained in laboratory microcosms for up to $5 \mathrm{~d}$.

\section{MATERIAL AND METHODS}

Materials. 1-( $\left.{ }^{14} \mathrm{C}\right)$-acetate $\left(56 \mu \mathrm{Ci} \mu \mathrm{mol}^{-1}\right)$ was supplied by New England Nuclear, Boston, MA, USA. Unisil brand silicic acid was obtained from Clarkson
Chemical Co., Williamsport, PA, USA. Glass-distilled solvents (Burdick und Jackson, Muskegon, WI, USA) or freshly redistilled analytical grade chloroform (Mallinkrodt, St. Louis, MO, USA) were used. Derivatizing reagents and authentic standards were purchased from Pierce Chemical Co., Rockford, IL, and Aldrich Chemical Co., St. Louis, MO. Fused silica Capillary GLC Durabond columns (DB-1) were supplied by J\&W Laboratories, Roncho Cordova, CA, USA.

Study site. Sediments used for the sieving disturbance experiment were obtained in July 1983 from an intertidal sandy-bottom site adjacent to the Florida State University Marine Laboratory, Franklin County, Florida, USA $\left(29^{\circ} 52^{\prime} \mathrm{N}, 84^{\circ} 31,5^{\prime} \mathrm{W}\right)$.

Experimentation. Two adjacent $1 \mathrm{~m}^{2}$ quadrats were established ca $10 \mathrm{~m}$ from shore (mean high water). One quadrat was sampled. Nine cores were taken and 3 replicate cores were randomly assigned to each of 3 assays. Samples were returned to the marine laboratory for processing. These samples served to characterize the ambient sediments. The top $2 \mathrm{~cm}$ (approximate) of sediment was removed from the second quadrat and returned to the marine laboratory for sieving. The sediment was passed through a $998 \mu \mathrm{m}$ sieve using a minimum of seawater. The sieved sediment was thoroughly mixed by hand and placed into 48 numbered $250 \mathrm{ml}$ Kimax beakers. The microcosms were maintained in a laboratory greenhouse in $20 \mathrm{~cm}$ of flowing seawater (1000 $\left.\mathrm{mI} \mathrm{min}^{-1}\right)$.

Beakers were randomly assigned to a sample time and replicate number. Six extra beakers were also scored for replacement, if needed, of any lost beakers. Three replicate beakers were sampled at each sample time. Beakers were sampled immediately after placement in the greenhouse and at $2,4,8,12,48,72$, and $120 \mathrm{~h}$ later. Three $2.5 \mathrm{~cm}$. ID cores were taken from each beaker One core was used for lipid analysis, one core for ${ }^{14} \mathrm{C}$-acetate incorporation into lipid, and one core for methyl- $\left({ }^{3} \mathrm{H}\right)$-thymidine incorporation into DNA. In all cases the top $2 \mathrm{~cm}$ of sediment was analyzed. Samples, when necessary, were inoculated and incubated on site. All samples were fixed and transported on ice to the main campus laboratory for processing.

Lipid extraction. Sediments were extruded into solvent-rinsed $300 \mathrm{ml}$ polypropylene centrifuge bottles containing $75 \mathrm{ml}$ methanol, $37.5 \mathrm{ml}$ chloroform and $25 \mathrm{ml}$ phosphate buffer $(50 \mu \mathrm{M}, \mathrm{pH} 7.4$ ) (White et al. 1979). The mixtures were allowed to stand for $24 \mathrm{~h}$ at $4^{\circ} \mathrm{C}$ as a single phase. The sediments and extraction mixtures were transferred to separatory funnels and the centrifuge bottles washed twice with $18.75 \mathrm{ml}$ of chloroform, followed by 3 washes of $12.5 \mathrm{ml}$ of water All washes were added to the separatory funnels, shaken vigorously, and the extraction mixture allowed to separate into 2 phases overnight. The chloroform layer 
(containing the lipid) was filtered through a tared Whatman $2 \mathrm{~V}$ filter, recovered, and dried. The sediment was recovered in the filter, dried to a constant weight and dry weight determined gravimetrically.

Lipid partitioning. The dried lipid was resuspended in $1 \mathrm{ml}$ of chloroform and two $100 \mu \mathrm{l}$ aliquots removed for analysis of total phospholipid phosphate (LPO4). The remaining lipid was placed on a previously prepared silicic acid column. The preparation of the column and the partitioning of the lipid into neutral lipid, glycolipid and phospholipid fractions were as described in Findlay \& White (1987).

Phospholipid phosphate. Lipid samples were digested in $23 \%(\mathrm{v} / \mathrm{v})$ perchloric acid for $2 \mathrm{~h}$ at $200^{\circ} \mathrm{C}$ and the phosphate determined colorimetrically (White et al. 1979).

Ester-linked phospholipid fatty acids. Ester-linked, phospholipid fatty acids (PLFA) were analyzed as their methyl esters using a modification of the procedures of Bobbie \& White (1980). The dried phospholipid fraction was subjected to mild alkaline transesterification and the resulting fatty acid methyl esters purified by thinlayer chromatography. The purified fatty acid methyl esters were identified and quantified using a Varian 3700 gas chromatograph equipped with an autosampler, flame-ionization detector, and a $60 \mathrm{~m}$ DB-1 fusedsilica capillary column. The abundances of all identified fatty acid methyl esters were summed to yield total ester-linked, phospholipid fatty acids (TPLFA).

Poly-beta-hydroxyalkanoates (PHA) were analyzed using the chloroform-methanol extraction method described in Findlay \& White (1987).

Muramic acid. The sediment was recovered after lipid extraction and analyzed for muramic acid (MA) as described in Findlay et al. (1983).

Radioactive incorporations. The ratio of the relative rates of $1-\left({ }^{14} \mathrm{C}\right)$-acetate incorporation into PLFA to incorporation into PHA (14CPLFA/14CPHA) was determined using the injection technique described in Findlay et al. (1985). The point of injection was $1.0 \mathrm{~cm}$ below the sediment-water interface. The relative rate of ${ }^{14} \mathrm{C}$-acetate incorporation into PLFA per unit biomass (a measure of microbial growth; Findlay et al. 1985) was calculated using the average $\mu$ moles LPO4 for the appropriate time and treatment.

The rate of methyl- $\left({ }^{3} \mathrm{H}\right)$-thymidine incorporation into DNA was determined using the method of Moriarty \& Pollard (1982). Sediments were extruded from the cores into plastic weighing dishes and mixed with a spatula. Approximately $1.5 \mathrm{~g}$ wet weight of the mixed sediments were placed in $50 \mathrm{ml}$ plastic screw-cap test tubes with $2 \mathrm{ml}$ of filtered seawater containing $65 \mu \mathrm{Ci}(50 \mathrm{Ci}$ $\left.\mathrm{mmol}^{-1}\right)$ of methyl- $\left({ }^{3} \mathrm{H}\right)$-thymidine. The test tubes were shaken and the samples incubated for $20 \mathrm{~min}$. The incubations were stopped and the samples preserved by adding $5 \mathrm{ml}$ of a solution of $70 \%$ ethanol and $5 \%$ formaldehyde in $25 \mathrm{ppt}$ artificial seawater. The samples were transported to the laboratory on ice and the labelled DNA was extracted. Calculations of methyl$\left({ }^{3} \mathrm{H}\right)$-thymidine incorporation into DNA per unit biomass were made using the average umoles LPO4 per $g$ dry weight of sediment for the appropriate time and treatment.

Statistical analysis. The sieving disturbance experiment was designed to be descriptive. Four t-tests were used to facilitate discussion of changes observed among several of the sampling times. These comparisons were performed to determine if sieved sediments were significantly different from ambient sediments, and if the first 2 changes following sieving were significant. Specifically, for measures that declined following sieving, the 4 tests were: (1) the value for ambient sediments was compared to the value for sieved sediments, (2) the value for ambient sediments was compared to the first minimum value, (3) the first minimum value was compared to the following relative maximum value, and, (4) values for the ambient sediments and the relative maximum were compared. For measures that increased following sieving, the 4 tests were: (1) the value for ambient sediments was compared to the value for sieved sediments, (2) the value for ambient sediments was compared to the first maximum value, (3) the first maximum value was compared to the following relative minimum value, and, (4) values for the ambient sediments and the relative minimum were compared. Data were natural log transformed prior to statistical analysis.

Groups of phospholipid fatty acids appeared to have similar patterns of change over the course of the experiment. An a posteriori cluster analysis was used to confirm these groupings. Fatty-acids profiles (Appendix 1) were transformed by dividing the nmoles of fatty acid measured at each sampling time by the maximum nmoles of that fatty acid recorded during the experiment. This allowed analysis of the patterns of change independent of the absolute values of the data (Pielou 1984). Cluster analysis was performed using the cluster sub-program available in Statistical Package for the Social Sciences (SPSS, Inc., Chicago, IL, USA). The squared Euclidean measure of distances and average linkage between groups were utilized.

\section{RESULTS}

Short-term metabolic status, measured using the ratio $14 \mathrm{CPLFA} / 14 \mathrm{CPHA}$, was significantly higher immediately following sieving, obtained a maximum value $2 \mathrm{~h}$ after the disturbance, and returned to ambient values $8 \mathrm{~h}$ after the sediments were sieved (Table 1, Fig. 1A). This ratio continued to decline to a 
Table 1. Effect of sieving on microbial activity and short-term metabolic status. All data given as means \pm SD, $n=3$. PLFA: phospholipid fatty acids; PHA: poly-beta-hydroxyalkanoates; LPO4: total phospholipid phosphate

\begin{tabular}{|c|c|c|c|c|c|}
\hline $\begin{array}{l}\text { Time }(\mathrm{h}) \\
\text { after sieving }\end{array}$ & $\begin{array}{l}\text { DPM's PLFA/ } \\
\text { DPM's PHA }\end{array}$ & \multicolumn{2}{|c|}{$\begin{array}{l}\text { pmol thymidine incorporated into } \\
\text { DNA min }{ }^{-1} \mu \mathrm{mol}^{-1} \text { LPO4 }\end{array}$} & \multicolumn{2}{|c|}{$\begin{array}{l}\text { nmol acetate incorporated into } \\
\text { phospholipid min } \text { m }^{-1} \mathrm{~mol}^{-1} \text { LPO4 }\end{array}$} \\
\hline $\begin{array}{l}\text { Ambient } \\
\text { sediment }\end{array}$ & $0.37 \pm 0.04$ & \multicolumn{2}{|l|}{$2.13 \pm 0.40$} & \multicolumn{2}{|l|}{$2.56 \pm 1.50$} \\
\hline $\begin{array}{l}\text { Sieved } \\
\text { sediment }\end{array}$ & $0.53 \pm 0.02$ & \multicolumn{2}{|l|}{$0.94 \pm 0.12$} & \multicolumn{2}{|l|}{$0.56 \pm 0.16$} \\
\hline 2 & $0.61 \pm 0.10$ & \multicolumn{2}{|l|}{$1.29 \pm 0.43$} & \multicolumn{2}{|l|}{$1.09 \pm 0.31$} \\
\hline 4 & $0.57 \pm 0.10$ & \multicolumn{2}{|l|}{$1.54 \pm 0.46$} & \multicolumn{2}{|l|}{$0.53 \pm 0.11$} \\
\hline 8 & $0.42 \pm 0.08$ & \multicolumn{2}{|l|}{$1.39 \pm 0.33$} & \multicolumn{2}{|l|}{$0.54 \pm 0.13$} \\
\hline 12 & $0.39 \pm 0.07$ & \multicolumn{2}{|l|}{$1.40 \pm 0.26$} & \multicolumn{2}{|l|}{$0.52 \pm 0.18$} \\
\hline 24 & $0.39 \pm 0.14$ & \multicolumn{2}{|l|}{$1.43 \pm 0.43$} & \multicolumn{2}{|l|}{$0.64 \pm 0.27$} \\
\hline 48 & $0.27 \pm 0.06$ & \multicolumn{2}{|l|}{$1.74 \pm 1.21$} & \multicolumn{2}{|l|}{$0.54 \pm 0.13$} \\
\hline 72 & $0.18 \pm 0.05$ & \multicolumn{2}{|l|}{$1.61 \pm 0.52$} & \multicolumn{2}{|l|}{$0.47 \pm 0.07$} \\
\hline 120 & $0.39 \pm 0.04$ & \multicolumn{2}{|l|}{$1.33 \pm 0.22$} & \multicolumn{2}{|l|}{$0.74 \pm 0.12$} \\
\hline \multicolumn{6}{|c|}{ Statistical summary ${ }^{a}$} \\
\hline PLFA/PHA & Significance & ${ }^{3} \mathrm{H}$-thymidine & Significance & ${ }^{14} \mathrm{C}$-acetate & Significance \\
\hline Ambient vs sieved & $\mathrm{p}<0.01$ & Ambient vs sieved & $p<0.01$ & Ambient vs sieved & $\mathrm{p}<0.05$ \\
\hline Ambient vs 1 st $\max ,(2 \mathrm{~h})$ & $\mathrm{p}<0.05$ & Ambient vs 1st min. (sv) & $\mathrm{p}<0.01$ & Ambient vs 1st min. (sv) & $\mathrm{p}<0.05$ \\
\hline 1st max. vs rel. min. $(12 \mathrm{~h})$ & $\mathrm{p}<0.05$ & 1st min. vs rel. max. (4 h) & $p<0.05$ & 1st min. vs rel. max. $(2 \mathrm{~h})$ & $\mathrm{p}<0.05$ \\
\hline Ambient vs rel. min. & ns & Ambient vs rel. max. & ns & Ambient vs rel. max. & ns \\
\hline
\end{tabular}

minimum value $3 \mathrm{~d}$ after sieving of the sediments and then increased to ambient levels at the end of the experiment.

Both measures of microbial growth were significantly lower immediately after sieving and then increased $2 \mathrm{~h}$ after the disturbance (Table 1, Fig. 1B, C). Growth rates, as measured as acetate incorporation into phospholipid, peaked $2 \mathrm{~h}$ after sieving while those measured as thymidine incorporation into DNA were highest $4 \mathrm{~h}$ after the disturbance. Growth rates throughout the rest of the experiment were lower than observed in the ambient sediment.

The 3 measures of microbial biomass were initially unchanged by sieving but then decreased to a minimum at either $2 \mathrm{~h}$ (LPO4) or $4 \mathrm{~h}$ (TPLFA, MA) after sieving (Table 2, Fig. 2). The decrease was greatest in TPLFA $(77 \%)$, moderate in MA $(40 \%)$, and smallest in LPO4 $(18 \%)$. All 3 measures then increased to levels approaching ambient values 8 and $12 \mathrm{~h}$ following the disturbance. Values for TPLFA, MA and LPO4 then remained essentially unchanged for the remainder of the experiment.

The amount of PHA, a measure of long-term metabolic status, recovered from the sediments was initially unchanged by sieving then decreased to zero $8 \mathrm{~h}$ after the disturbance. The recovery of this procaryotic storage material was much slower than the recovery of microbial biomass with values returning to ambient levels $24 \mathrm{~h}$ after sieving (Table 3, Fig. 3). Levels then decreased to ca $20 \%$ of those for ambient sediments for the remainder of the experiment. The

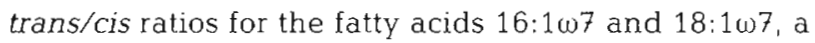
measure of stress or starvation, were unchanged by sieving but increased to a maximum value $4 \mathrm{~h}$ following the disturbance and returned to ambient values after 8 and $12 \mathrm{~h}$ (Table 3, Fig. 3). This pattern is virtually the opposite of the pattern observed for TPLFA. The ratios again increased and remained elevated for the remainder of the experiment.

Twenty-five individual PLFA were identified (Appendix 1). All fatty acids, as with TPLFA, were initially unaffected by sieving but then decreased in abundance to a minimum value $4 \mathrm{~h}$ after the disturbance. At $8 \mathrm{~h}$ after sieving the abundance of all the fatty acids had signifcantly increased. Cluster analysis revealed that the patterns of change in the individual fatty acids grouped into 4 distinct clusters (Fig. 4). A functional-group approach was utilized in the analysis of these patterns. Pure culture studies, laboratory manipulations on bacterial respiratory types, and descriptive field studies were the basis for assigning functional groups of microorganisms to the clusters obtained (see Appendix 2).

The fatty acids of Cluster 1, the microeucaryotic functional group, decreased following sieving with abundances falling to zero $4 \mathrm{~h}$ after the construction of the microcosms (Fig. 5, Appendix 1). These fatty acids 


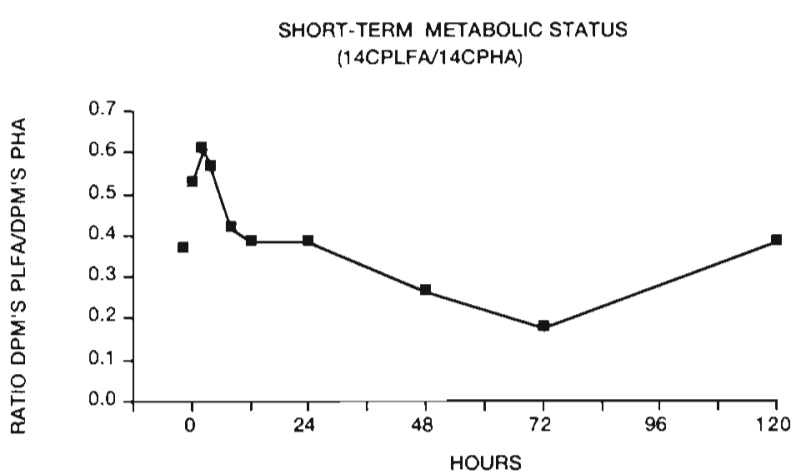

\section{ठ} RATE OF GROWTH ( $\mathrm{h}$ )

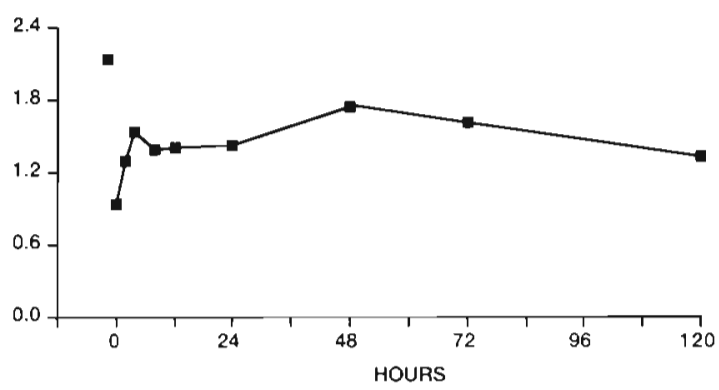

increased moderately $8 \mathrm{~h}$ following sieving and peak abundances occurred $24 \mathrm{~h}$ after the disturbance. Abundances again declined $48 \mathrm{~h}$ after sieving and remained very low, compared to ambient sediments, for the

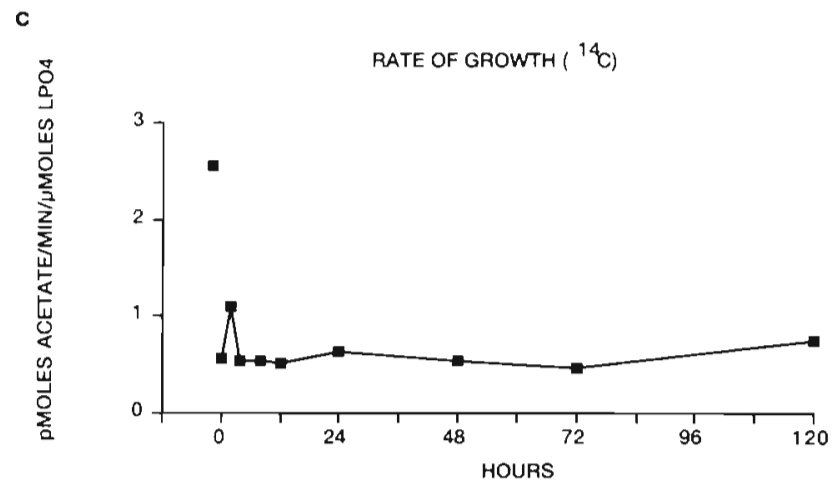

Fig. 1. Changes following sieving in the (A) short-term metabolic status and (B, C) growth rates of a estuarine sedimentary microbial community. Single point represents ambient sediments; zero time-point the sediments immediately after sieving and construction of the microcosms. Standard deviations and statistical analysis are given in Table 1

remainder of the experiment. The patterns of change in the mole-percent values [(moles individual fatty acid/ moles TPLFA) $\times 100$ ] were similar to the abundance changes in magnitude and time of occurrence.

The fatty acids of Cluster 2, a functional group composed of aerobic procaryotes and eucaryotes, also decreased $4 \mathrm{~h}$ after sieving with abundances falling to less than $10 \%$ of the levels in the ambient sediments. At 8 and $12 \mathrm{~h}$ after sieving the abundance of these fatty acids increased, but only between 50 and $75 \%$ of the

Table 2. Effect of sieving on microbial biomass. All data given as $u$ mol $\mathrm{g}^{-1}$ dry wt of sediment; means $\pm \mathrm{SD}, \mathrm{n}=3$

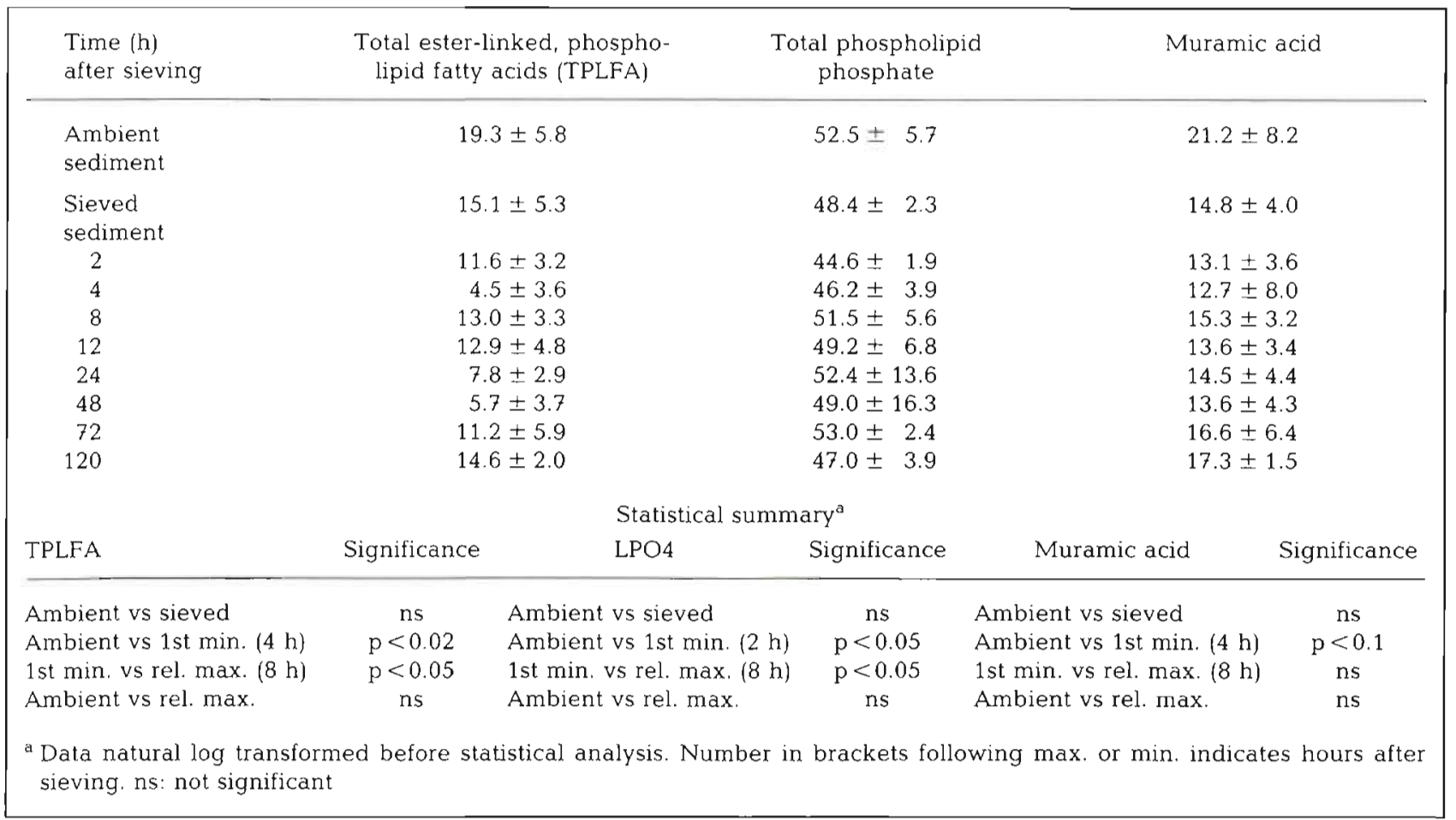


A

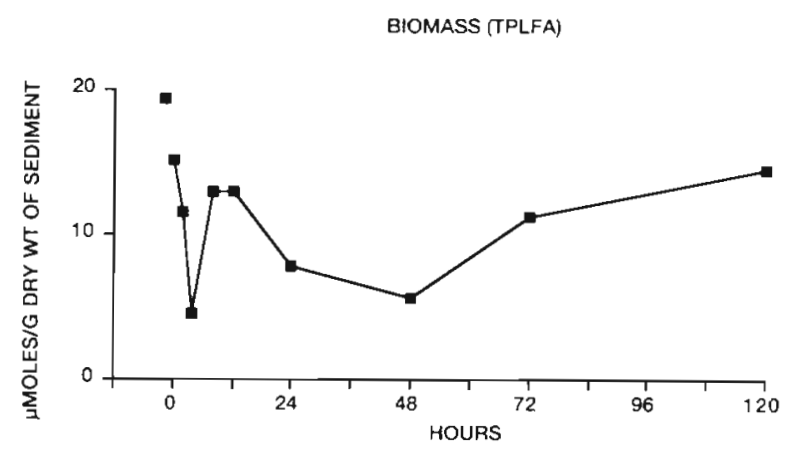

B

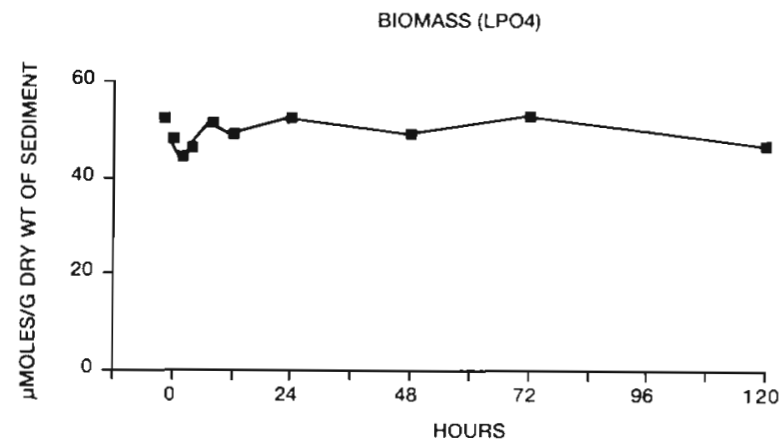

levels in the ambient sediments. The fatty acids again decreased in abundance $24 \mathrm{~h}$ after sieving and then remained fairly constant for the remainder of the experiment. The patterns of change in the mole-per-

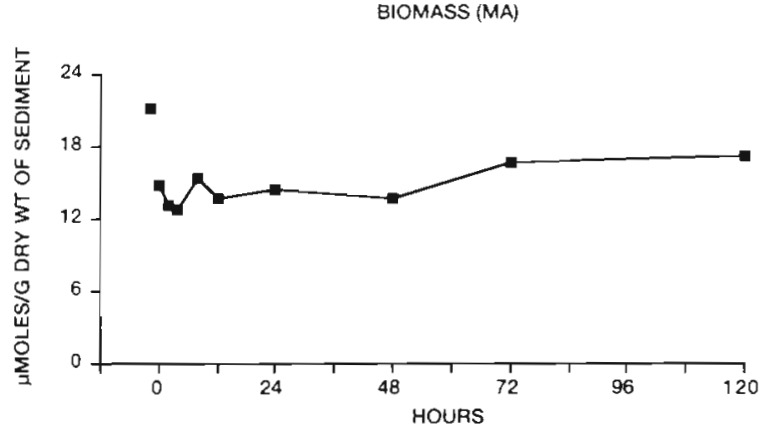

Fig. 2. Changes following sieving in the biomass of a estuarine sedimentary microbial community. Single point represents the ambient sediments; zero time-point the sediments immediately after sieving and construction of the microcosms. Standard deviations and statistical analysis are given in Table 2

cent values were similar to the abundance changes in magnitude and time of occurrence.

The fatty acids of Cluster 3, representing Grampositive and anaerobic procaryotes, showed several unique trends. Abundance of these fatty acids remained high $2 \mathrm{~h}$ after sieving and the decreases $4 \mathrm{~h}$ after the disturbance were smaller (average $75 \%$ ) than for the fatty acids from Clusters 1 or 2 . Increases $8 \mathrm{~h}$ after sieving were similar to those observed in Cluster 2. At the end of the experiment, the abundance and mole-percent values of Cluster 3 fatty acids were comparable to those of the ambient sediment.

Table 3. Effect of sieving on long-term microbial metabolic status. All data given as means $\pm \mathrm{SD}, \mathrm{n}=3 ; \mathrm{PHA}$ as $\mathrm{nmol} \mathrm{g}^{-1} \mathrm{dry}$ wt of sediment

\begin{tabular}{|c|c|c|c|c|c|c|}
\hline $\begin{array}{l}\text { Time }(\mathrm{h}) \\
\text { after sieving }\end{array}$ & \multicolumn{3}{|c|}{ PHA } & 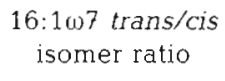 & \multicolumn{2}{|c|}{$\begin{array}{l}\text { 18: } 1 \omega 7 \text { trans/cis } \\
\text { isomer ratio }\end{array}$} \\
\hline $\begin{array}{l}\text { Ambient } \\
\text { sediment }\end{array}$ & \multicolumn{3}{|c|}{$2275 \pm 417$} & $0.080 \pm 0.011$ & \multicolumn{2}{|c|}{$0.021 \pm 0.008$} \\
\hline $\begin{array}{l}\text { Sieved } \\
\text { sediment }\end{array}$ & \multicolumn{3}{|c|}{$1113 \pm 1733$} & $0.081 \pm 0.017$ & \multicolumn{2}{|c|}{$0.022 \pm 0.008$} \\
\hline 2 & \multicolumn{3}{|c|}{$177 \pm 306$} & $0.165 \pm 0.080$ & \multicolumn{2}{|c|}{$0.043 \pm 0.013$} \\
\hline 4 & $23 \pm$ & 28 & & $0.905 \pm 0.774$ & \multicolumn{2}{|c|}{$0.057 \pm 0.031$} \\
\hline 8 & $0 \pm$ & 0 & & $0.116 \pm 0.039$ & \multicolumn{2}{|c|}{$0.034 \pm 0.029$} \\
\hline 12 & $453 \pm$ & 582 & & $0.087 \pm 0.006$ & \multicolumn{2}{|c|}{$0.018 \pm 0.006$} \\
\hline 24 & $2507 \pm$ & 1708 & & $0.241 \pm 0.211$ & \multicolumn{2}{|c|}{$0.021 \pm 0.015$} \\
\hline 48 & $577 \pm$ & 230 & & $0.302 \pm 0.188$ & \multicolumn{2}{|c|}{$0.054 \pm 0.003$} \\
\hline 72 & $225 \pm$ & 148 & & $0.240 \pm 0.104$ & \multicolumn{2}{|c|}{$0.037 \pm 0.025$} \\
\hline 120 & $285 \pm$ & 120 & & $0.350 \pm 0.189$ & \multicolumn{2}{|c|}{$0.043 \pm 0.010$} \\
\hline \multicolumn{7}{|c|}{ Statistical summary } \\
\hline PHA & Significance & & $16: \omega^{7} t / c$ ratio & Significance & $18: 107 t / C$ ratio & Significance \\
\hline Ambient vs sieved & ns & Am & bient vs sieved & ns & Ambient vs sieved & ns \\
\hline Ambient vs 1 st min. $(8 \mathrm{~h})$ & $p<0.01$ & Am & bient vs 1 st max. $(4 \mathrm{~h})$ & $p<0.05$ & Ambient vs 1 st max. (4 h) & $p<0.05$ \\
\hline 1st min. vs rel max. (24 h) & $p<0.05$ & 1 st & max. vs rel. min. (12 h) & $p<0.05$ & 1st min. vs rel. min. (12 h) & $\mathrm{p}<0.05$ \\
\hline Ambient vs rel. max. & ns & Am & bient vs rel. min. & ns & Ambient vs rel. max. & ns \\
\hline
\end{tabular}



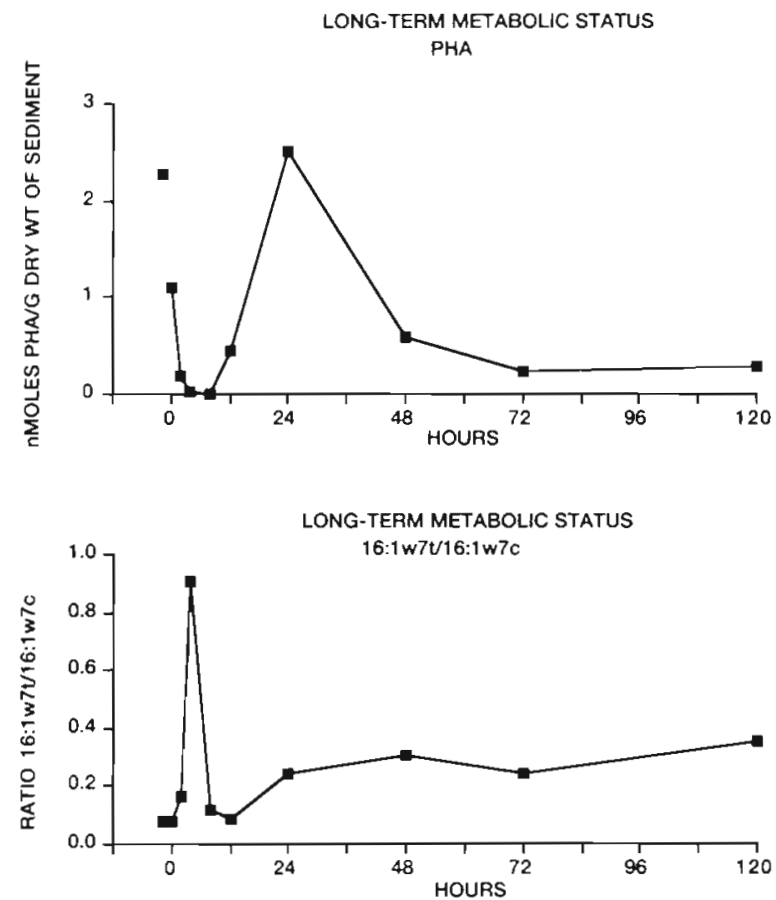

c

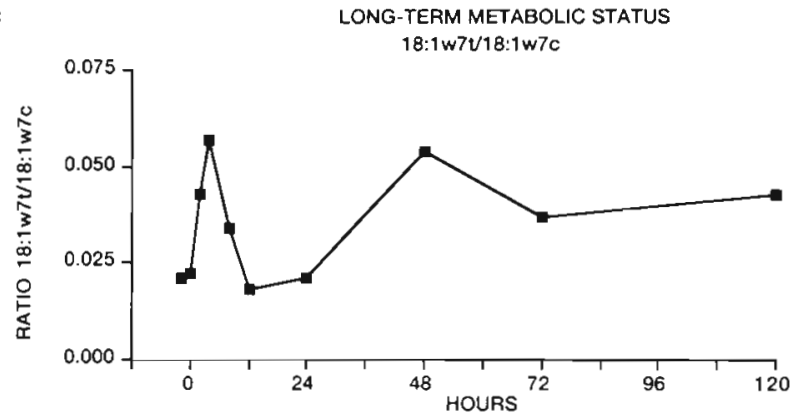

Fig. 3. Changes following sieving in the long-term metabolic status of a estuarine sedimentary microbial community. Single point represents the ambient sediments; zero time-point the sediments immediately after sieving and construction of the microcosms. Standard deviations and statistical analysis are given in Table 3

The fatty acids of Cluster 4 , a functional group made up of sulfate-reducing bacteria and other anaerobic procaryotes, showed the smallest percentage decrease abundance $4 \mathrm{~h}$ after sieving. The decreases ranged from 33 to $50 \%$. The abundance of Cluster 4 fatty acids increased $8 \mathrm{~h}$ after sieving to a level comparable to the ambient sediments. At the end of the experiment the abundance of Cluster 4 fatty acids was greater in the microcosm sediments than in ambient sediments. The mole-percent values for each of these fatty acids increased to a maximum $4 \mathrm{~h}$ after sieving and then decreased at 8 and $12 \mathrm{~h}$. After $5 \mathrm{~d}$ in the laboratory, the mole-percent values of the Cluster 4 fatty acids were greater in the microcosm sediments than in ambient sediments.

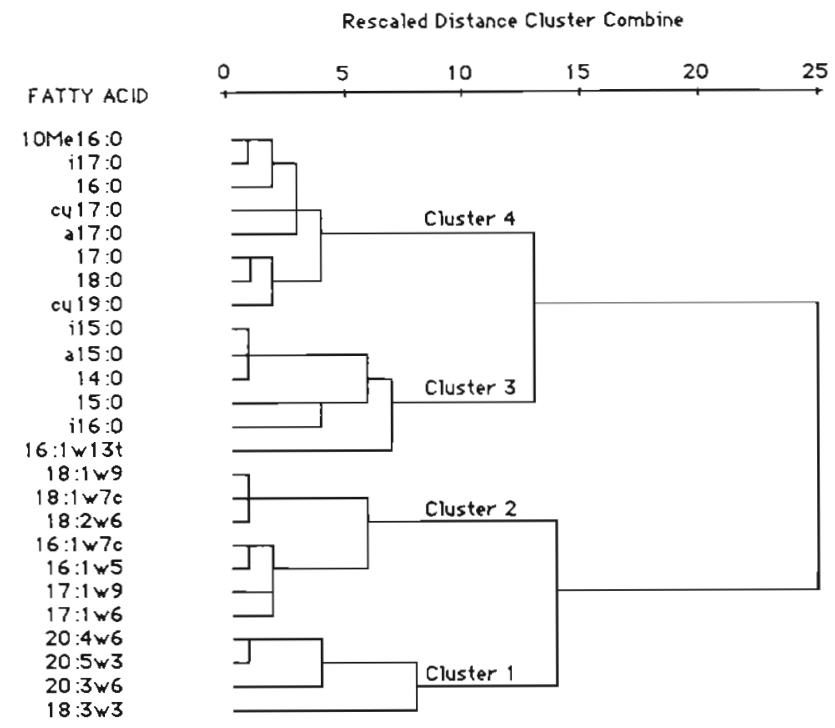

Fig. 4. Cluster analysis of the pattern of changes in the individual ester-linked, phospholipid fatty acids following sieving

\section{DISCUSSION}

The effects of sieving on the microbial community varied with time following the disturbance. Immediately following sieving, the ratio of acetate-incorporation into phospholipid versus acetate-incorporation into PHA indicated that short-term metabolic status was shifted towards phospholipid synthesis. In addition, microbial growth rates were depressed and microbial biomass was unchanged. At 2 and $4 \mathrm{~h}$ after the disturbance, short-term metabolic status was still shifted towards phospholipid synthesis and growth rates were comparable to those of the ambient sediments. Microbial biomass was now significantly less in the disturbed sediments. Long-term measures of metabolic status (PHA, trans/cis ratios) indicate that the community was undergoing metabolic stress, possibly starvation or anoxia (Findlay \& White 1983b, Guckert et al. 1985, 1986). Differential changes in the mole-percent values of the individual ester-linked, phospholipid fatty acids indicate that the relative importance of some functional groups within the microbial community had increased while others had declined. At 8 and $12 \mathrm{~h}$ after the disturbance the effects were minimal. The short-term metabolic status and total microbial biomass were comparable to the ambient sediments. The microbial community structure was once again similar to that of the ambient sediments and markedly different from the community several hours earlier. The levels of PHA were beginning to recover and the trans/cis ratios were again similar to those of the ambient sediments. Only microbial growth rates were significantly lower.

Sieving was initially deleterious. The effects were an immediate reduction in microbial growth rates, 

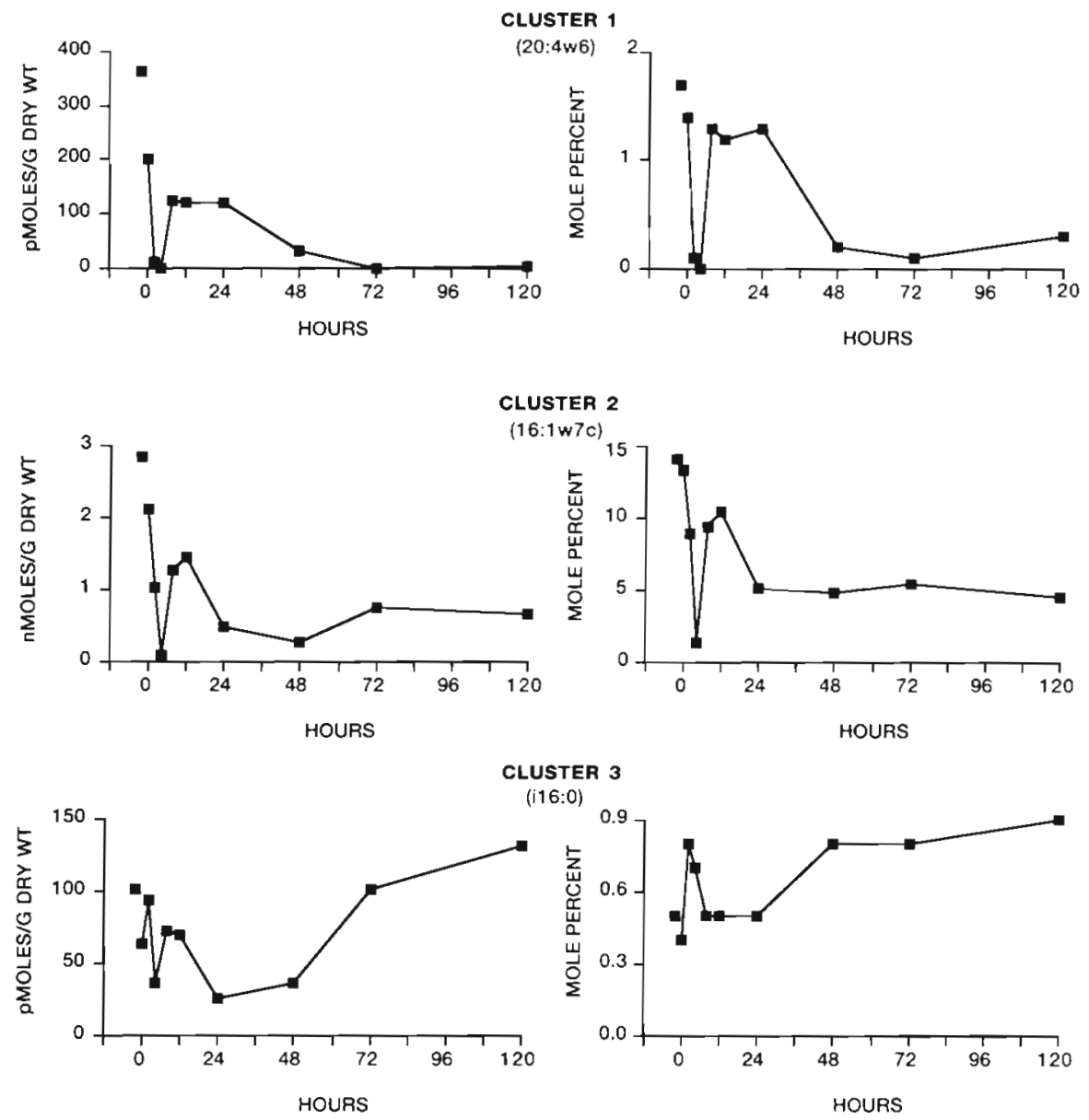

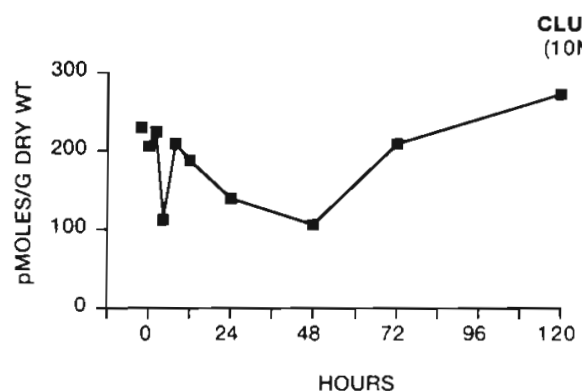

CLUSTER 4

Me16:0)

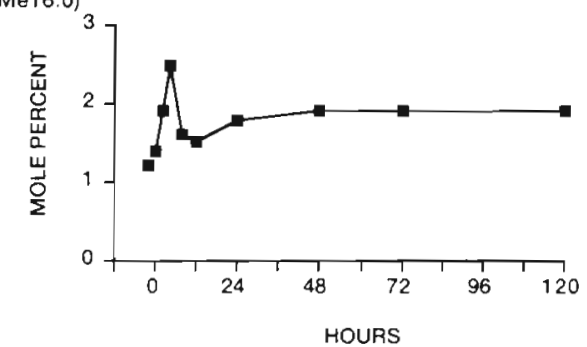

Fig. 5. Example of the pattern of changes in the abundance and molepercent values of Cluster $1,2,3,4$ fatty acids (20:406, $16: 1017 \mathrm{C}, \quad$ i16:0, 10Me16:0, respectively; from Appendix 1) induced by sieving of the sediments and their maintenance in laboratory microcosms and a decrease in microbial biomass and storage products, and were also evidenced by the increase in the trans/cis fatty acid ratios. Sieving presumably abrades sediments and has been shown to transform heterogeneous sediments containing numerous complex biological and chemical gradients to a homogeneous mixture (Aller \& Yingst 1985). Physical abrasion has been proposed to restrict microorganisms to the protected areas of sand grains (Meadows \& Anderson 1967). Hoppe (1984) viewed attachment within protected sites of a sand grain as necessary for microbe survival in areas of high mechanical disturbance. Sediments with surface irregularities support a greater microbial biomass than those having smooth surfaces (Nickels et al. 1981) and microscopic analysis of distribution patterns indicates that microbes are not uniformly distributed over the surfaces of sand grains, but are concentrated in cracks, crevices, and pits (Weise \& Rheinheimer 1978). The initial deleterious effects observed following sieving may arise from abrasion and/or the exposure of the microorganisms to unfavorable metabolic conditions caused by the disruption of the gradients commonly associated with estuarine sediments.

The microbial community, first adversely affected by sieving, rapidly showed signs of recovery. Short-term metabolic status was immediately shifted towards cellular growth. Microbial growth increased several hours 
after sieving and microbial biomass was comparable to that of ambient sediments after $8 \mathrm{~h}$. It is widely argued that bacteria in nature experience restricted rates of growth due to limitation of essential resources (e.g. Tempest \& Neijssel 1978, Gottschal 1985). The stimulatory effects of disturbance may arise by a reduction of resource limitation; specifically, by opening space for microbial colonization and growth, by increasing nutrient availability, and by decreasing the concentration of inhibitory metabolites.

The differential responses of the various fatty-acid clusters following sieving indicated the functional groups within the microbial community varied in their response to the disturbance. The large decrease in abundance of Clusters 1 and 2 fatty acids $4 \mathrm{~h}$ after sieving indicates that aerobic organisms, both eucaryotic and procaryotic, were severely affected. The drop in mole-percent values of these fatty acids indicated a disproportionate negative effect on the aerobic organisms. The large increase in the trans/cis ratios of fatty acids indicates aerobic organisms were under stressful metabolic conditions at this time (Guckert et al. 1986). The moderate decrease in Cluster 4 fatty acids indicates that Desulfobacter and other anaerobic bacteria were only moderately affected. The increase in molepercent values $4 \mathrm{~h}$ after sieving indicates that this group of organisms increased in relative importance within the community. The presence of mixed microcolonies (Hirsch 1984, White 1984), composed of an outer layer of aerobes more susceptible to abrasion, and an inner, more protected core of anaerobes would account for a differential loss of aerobic microorganisms.

All 4 groups of organisms rapidly recovered from the adverse effects of sieving. The 3 functional groups dominated by bacteria $(2,3$ and 4$)$ showed significant increases in biomass $8 \mathrm{~h}$ after the disturbance. The recovery of microeucaryotic biomass, as indicated by the abundance of Cluster 1 fatty acids, was slower than the recovery of procaryotic biomass, with peak eucaryotic biomass occurring $24 \mathrm{~h}$ after the disturbance Mole-percent values indicated that the relative abundance of microeucaryotes at this time was similar to ambient relative abundances.

The microcosm sediments failed to develop the thin layer of oxidized sediment present in the natural environment. After $5 \mathrm{~d}$, Cluster 1 fatty acids had significantly decreased indicating a loss of microeucaryotic biomass. Clusters 3 and 4 fatty acids increased relative to Cluster 2 fatty acids indicating a relative increase in anaerobic organisms compared to aerobic organisms. PHA abundances decreased and the trans/cis ratios increased indicating aerobic microbes were under metabolic stress. These changes in microbial community structure are similar to those reported by Federle and co-workers (1983a, 1983b, 1986). In a series of carefully controlled experiments they determined the microbial community structure of sediments at a nearby site in St. Georges Sound and the effects of maintaining these sediments in the laboratory. Microcosms were carefully constructed to maintain sediment integrity and minimize disturbance. In situ light, salinity, temperature and dissolved oxygen were controlled. After 2 wk, a discriminant analysis indicated that microcosm sediments were depauprate in 16:107 and 18:2w6 (Cluster 2 fatty acids, this study) and enriched in 15:0 (Cluster 3 fatty acids, this study) when compared to field control sediments.

Near-shore and intertidal sediments are exposed to significant wave and tidal action. Wave-generated hydrostatic pressure has been shown to increase watersoluble transport, increasing oxygen penetration into sediments (Steele et al. 1970, Riedl et al. 1972, Webb \& Theodor 1972). The combined effects of reduced circulation within the sediment and the loss of controlling biotic factors may have induced the changes observed in the microcosm sediments after $5 \mathrm{~d}$. Reduced availability of oxygen in the sediments may have caused the loss of microeucaryotic biomass, the decrease in aerobic bacteria and the increase in sulfate-reducing and other anaerobic bacteria. The decrease in abundance of PHA without an increase in the growth rate or a shift in short-term metabolic status toward cellular growth suggests that carbon and energy had become limiting. The rise in the trans/cis fatty acid ratio supports this conclusion. This may be caused by the loss of detrital carbon inputs from overlying waters and/or decreased rates of flux of reduced carbon from depth. The reduced rates of growth may also be a consequence of reduced availability of carbon and energy.

The results of our study, in agreement with the conclusions of Federle et al. (1986), suggest that care should be taken when designing a microcosm study, especially sieved-sediment microcosms commonly used to study macrofaunal-microbial interactions. Sediments should be characterized prior to microcosm construction to allow assessment of changes induced during construction. In addition, experimental designs should allow for detection of changes arising from uncoupling the sedimentary community from biotic and abiotic controls.

In summary, the dramatic changes observed in the microbial community in the $24 \mathrm{~h}$ following sieving demonstrates the potential for disturbance playing an important role in structuring microbial communities in marine sediments. In addition, the changes noted after sediments were maintained in the laboratory for $5 \mathrm{~d}$ suggest that abiotic factors that increase oxygen penetration into the sediments also influence microbial community structure. 


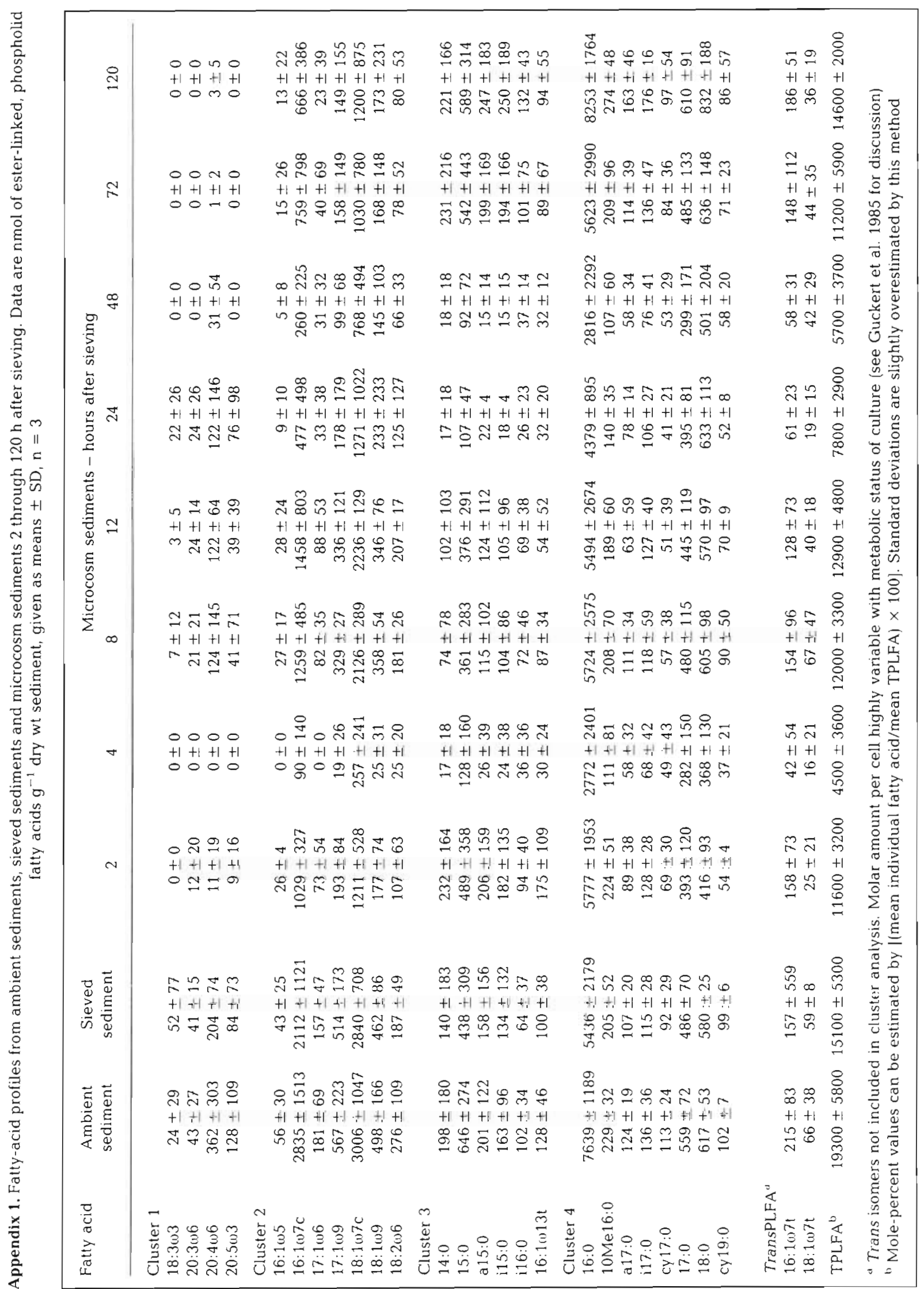







Acknowledgements. We appreciate helpful discussions with F. Dobbs and thank S. Hacker for insightful comments on the manuscript. Drs D. Meeter and J. Ault provided helpful guidance on the correct application of statistical procedures. This research was supported in part by grants N-0014-82-C0404 and N-0014-83-K0276 from the Office of Naval Research and OCE-80-19757 from the National Science Foundation.

\section{LITERATURE CITED}

Aller, R. C. (1978). Experimental studies of changes produced by deposit feeders on pore water, sediment, and overlying water chemistry. Am. J. Sci. 217: 1185-1234

Aller, R. C. (1982). The effects of macrobenthos on chemical properties of marine sediment and overlying water. In: McCall, P. L., Tevesz, M. J. S. (eds.) Animal-sediment relations, Vol. 2, The biogenic alteration of sediments. Plenum Press, New York, p. 53-102

Aller, R. C., Yingst, J. Y (1985). Effects of the marine depositfeeders Heteromastus filiformis (Polychaeta), Macoma balthica (Bivalvia), and Tellina texana (Bivalvia) on averaged sedimentary solute transport, reaction rates, and microbial distribution. J. mar. Res. 43: 615-645

Berner, R. A. (1976). The benthic boundary from the viewpoint of a geochemist. In: McCave, N. (ed.) The benthic boundary layer. Plenum Press, New York, p. 33-53

Bobbie, R. J., White, D. C. (1980). Characterization of benthic microbial community structured by high resolution gas chromatography of fatty acid methyl esters. Appl environ. Microbiol. 39: 1212-1222

Boon, J. J., DeLeeuw, G. W., Hoek, G. J., Vosjan, J. H. (1977). Significance and taxonomic value of iso and anteiso monoenoic fatty acids and branched beta-acids in Desulfovibrio desulfuricans. J. Bacteriol. 129: 1183-1191

Boon, J. J., Liefkens, W., Rijpstra, W I. C., Baas, M., De Leeuw, J. W. (1978). Fatty acids of Desulfovibrio desulfuricans as marker molecules in sedimentary environments. In: Krumbein, W. E. (ed.) Environmental and geomicrobiology biogeochemistry. Ann Arbor Science Publishers, Ann Arbor, p. 355-372

Dale, N. G. (1974). Bacteria in intertidal sediments: factors related to their distribution. Limnol. Oceanogr. 19: 509-518

DeFlaun, M. F. Mayer, L. M. (1983). Relationship between bacteria and grain surface in intertidal sediments. Limnol. Oceanogr. 28: 873-881

Dobbs, F. C., Guckert, J. B. (1988a). Callianassa trilobata (Crustacea: Thalassinidea) influences abundance of meiofauna and biomass, composition, and physiologic state of microbial communities within its burrow. Mar. Ecol. Prog. Ser. 45: 69-79

Dobbs, F. C., Guckert, J. B. (1988b). Microbial food resources of the macrofaunal-deposit feeder Ptychodera bahamensis (Hemichordata: Enteropneusta). Mar. Ecol. Prog. Ser. 45: $127-136$

Dowling, N. J. E., Widdel, F., White, D. C. (1986). Phospholipid ester-linked fatty acid biomarkers of acetate-oxidizing sulfate-reducers and other sulfide-forming bacteria. J. gen. Microbiol. 132: 1815-1825

Edlund, A., Nichols, P. D., Roffey, R., White, D. C. (1985). Extractable and lipopolysaccharide fatty acid profiles from Desulfovibno species. J. Lipid Res. 26: 982-988

Erwin. J. A. (1973). Comparative biochemistry of fatty acids in eukaryotic microorganisms. In: Erwin, J. A. (ed.) Lipids and biomembranes of eukaryotic microorganisms. Academic Press, New York, p. 41-143
Federle, T W., Hullar, M. A., Livingston, R. J., Meeter, D. A., White, D. C. (1983a). Spatial distribution of biochemical parameters indicating biomass and community composition of microbial assemblies in estuarine mud flat sediments. Appl. environ. Microbiol. 45: 58-63

Federle, T W., Livingston, R. J., Meeter, D. A., White, D. C. (1983b). Modification of estuarine sedimentary microbiota by exclusion of epibenthic predators. J. exp. mar. Biol. Ecol. 73: 81-94

Federle, T. W., Livingston, R. J., Wolfe, L. E., White, D. C. (1986). A quantitative comparison of microbial community structure of estuarine sediments from microcosms and the field. Can. J. Microbiol. 32: 319-325

Fell, J. W., Findlay, R. H. (1987). The potential use of sterols and phospholipid fatty acids as taxonomic tools among teliospore-forming red yeast. In: De Hoog, G. S., Smith, M. Th., Weijman, A. C. M. (eds.) The expanding realm of yeast-like fungi. Elsevier Science Publishers, Amsterdam, p. $309-320$

Findlay, R. H., Fell, J. W., Coleman, N. K., Vestal, J. R. (1986) Biochemical indicators of the role of fungi and thraustochytrids in mangrove detrital systems. In: Moss, S. T (ed.) Biology of marine fungi. Cambridge University Press, Cambridge, p. 91-104

Findlay, R. H., Moriarty, D. J. W., White, D. C. (1983). Improved method of determining muramic acid from environmental samples. Geomicrobiology J. 3: 133-150

Findlay, R. H., Pollard, P. C., Moriarty, D. J. W., White, D. C. (1985). Quantitative determination of microbial activity and community nutritional status is estuarine sediments: evidence for a disturbance artifact. Can. J. Microbiol. 31: 493-498

Findlay, R. H., White, D. C. (1983a). The effects of feeding by the sand dollar Mellita quinquesperforata on the benthic microbial community. J. exp. mar. Biol. Ecol. 72: 25-41

Findlay, R. H., White, D. C. (1983b). Polymeric beta-hydroxyalkanoates from environmental samples and Bacillus megaterium. Appl. environ. Microbiol. 45: 71-78

Findlay, R. H., White, D. C. (1987). A simplified method for bacterial nutritional status based on the simultaneous determination of phospholipid and endogenous sturage lipid poly-beta-hydroxyalkanoate. J. Microbiol. Meth. 2: 275-293

Frankel, L., Mead, D. J. (1973). Mucilagenous matrix of some estuarine sands in Connecticut. J. sedim. Petrol. 43: 1090-1095

Gillian, F. T., Hogg, R. W. (1984). A method for the estimation of bacterial biomass and community structure in mangrove associated sediments. J. Microbiol. Meth. 2: 275-293

Gillian, F. T., Johns, R. B., Verhey. Tk. V., Nichols, P. D. (1983). Monounsaturated fatty acids as specific bacterial markers in marine sediments. [n: Bjoroy, M. (ed.) Advances in organic geochemistry 1981. Wiley and Sons Ltd. New York, p. 198-206

Gottschal, J. C. (1985). Some reflections on microbial competitiveness among heterotrophic bacteria. Antonie van Leeuwenhoek 51. 473-494

Gray, J. S. (1974). Animal-sediment relationships. Oceanogr Mar. Biol, A. Rev. 12: 223-261

Guckert, J. B., Antworth, C. P., Nichols, P. D., White, D. C. (1985). Phospholipid, ester-linked fatty acid profiles as reproducible assays for changes in prokaryotic community structure of estuarine sediments. FEMS Microbiol. Ecol. 31: $147-158$

Guckert, J. B., Hood, M. A., White, D. C. (1986). Phospholipid ester-linked fatty acid profile changes during nutrient deprivation of Vibrio cholerae: increases in trans/cis and 
proportions of cyclopropyl fatty acids. Appl. environ. Microbiol. 46: 930-940

Hirsch, P. (1984). Microcolony formation and consortia. In: Marshall, K. C. (ed.) Microbial adhesion and aggregation. Springer-Verlag, Berlin, p. 373-394

Holz, G. G., Jr (1981). Non-isoprenoid lipids and lipids metabolism of marine flagellates. Biochem. Physiol. Protozoa. $4: 301-332$

Hoppe, H. G. (1984). Attachment of bacteria: advantage or disadvantage for survival in the aquatic environment. In Marshall, K. C. (ed.) Microbial adhesion and aggregation. Springer-Verlag, Berlin, p. 283-301

Jones, J. G. (1979). Microbial activity in lake sediments with particular reference to electrode potential gradients. J. gen. Microbiol. 115: 19-21

Kaneda, T (1977). Fatty acids of the genus Bacillus: an example of branched-chain preference. Bact. Rev. 41: 391-418

Meadows, P. S., Anderson, J. G. (1967). Microorganisms attached to marine sand grains. J. mar. biol. Ass. U. K. 48: 161-175

Meyer, A. C. (1977). Sediment processing in a marine subtidal sandy bottom community. 1. Physical aspects. J. mar. Res. 35: 609-632

Moriarty, D. J. W., Pollard, P. C. (1982). Diel variation of bacterial productivity in seagrass (Zostera capricorni) beds measured by rate of thymidine incorporation into DNA. Mar Biol. 72: 165-173

Nickels, J. S., Bobbie, R. J., Martz, R. F., Smith, G. A., White, D. C., Richards, N. L. (1981). Effect of silicate grain shape, structure and location on the biomass and community structure of colonizing marine microbiota. Appl. environ. Microbiol. 41. 1261-1268

Parker, P. L., Van Ballen, C., Mauren, L. (1967). Fatty acid in eleven species of blue-green algae: geochemical significance. Science 155: 707-708

Parkes, R. J., Taylor, J. (1983). The relationship between fatty acid distributions and bacterial respiration types in contemporary marine sediments. Estuar. coast. Shelf Sci. 16: $173-189$

Pielou, E. C. (1984). The interpretation of ecological data, John Wiley and Sons, New York

Pritchard, P. H., Bourquin, A. W. (1984). The use of microcosms for evaluating of interactions between pollutants and microorganisms. Adv. microb. Ecol. 7: 133-215

Reichgott, M. R., Stevenson, L. H. (1978). Microbiological and physical properties of salt marsh and microecosystem sediments. Appl. environ. Microbiol. 36: 662-667

Rhoads, D. C. (1974). Organism-sediment relations on the muddy sea floor. Oceanogr. Mar. Biol. A. Rev. 12: 263-300

Rhoads, D. C., Boyer, L. F. (1982). The effects of marine benthos on physical properties of sediments: a successional perspective. In: McCall, P. L., Tevesz, M. J. S. (eds.) Animal-sediment relations, Vol. 2, The biogenic alteration of sediments. Plenum Press, New York, p. 3-52

Riedl, R. J., Huang, N., Machan, R. (1972). The subtidal pump: a mechanism of interstitial water exchange by wave action. Mar. Biol. 13: 210-221

This article was presented by Dr S. Y. Newell, Sapelo Island, Georgia, USA
Sayler, G. S., Parkins, R. E., Sherrill, T. W., Perkins, B. K., Reid, M. C., Schields, M. S., King, H. L., Davis, J. D. (1983). Microcosm and experimental pond evaluation of microbial community response to synthetic oil contamination in fresh water sediments. Appl. environ. Microbiol. 46: 1211-1218

Steele, J. H., Munro, A. L. S., Giese, G. S. (1970). Environmental factors controlling the epipsamic flora on beach and sublittoral sands. J. mar biol. Ass. U. K. 50: 907-918

Steneck, R. S., Watling, L. (1982). Feeding capabilities and limitation of herbivorous molluscs: a functional group approach. Mar. Biol. 68: 299-319

Suess, E. (1976). Nutrients near the depositional interface. In: McCave, N. (ed.) The benthic boundary layer. Plenum Press, New York, p. 57-79

Tempest, D. W., Neijssel, O. M. (1978). Eco-physiological aspects of microbial growth in aerobic nutrient-limited environments. In: Alexander, M. (ed.) Advances in microbial ecology, Vol.2. Plenum Press, New York, p. $105-153$

Volkman, J. K., Johns, R. B. (1977). The geochemical significance of potential isomers of unsaturated acids from an intertidal zone sediment. Nature, Lond. 267: 693-694

Wannigama, C. P., Volkman, J. K., Gillian, F. T., Nichols, P. D., Johns, R. B. (1981). A comparison of lipid components of the fresh and dead leaves and pneumatophores of the mangrove Avicennia marine. Phytochem. 20: 659-666

Wassef, M. K. (1977). Fungal lipids. Adv. Lipid Res. 15: $159-230$

Watling, L. (1988). Small-scale features of marine sediments and their importance to the study of deposit-feeding. Mar. Ecol. Prog. Ser. 47: 135-144

Webb, J. E., Theodor, J. L. (1972). Wave induced circulation in submerged sands. J. mar. biol. Ass. U. K. 52: 903-914

Weete, J. D. (1980). Lipid biochemistry of fungi and other organisms. Plenum Press, New York

Weise, W., Rheinheimer, G. (1978). Scanning electron microscopy and epifluorescence investigation of bacterial colonization of marine sand sediments. Microb. Ecol. 4: $175-188$

White, D. C. (1983). Analysis of microorganisms in terms of quantity and activity in natural environments. Symp. Soc. Gen. Microbiol. 34: 37-66

White, D. C. (1984). Chemical characterization of films. In Marshall, K. C. (ed.) Microbial adhesion and aggregation. Dahlem Konferenzen Life Sciences Research Report No. 31. Springer Verlag, Berlin and New York, p. 159-176

White, D. C. (1986). Quantitative physiochemical characterization of bacterial habitats. In: Poindexter, J. S., Leadbetter, E. R. (eds.) Bacteria in nature, Vol. 2. Plenum Press New York, p. 177-203

White, D. C., Davis, W. M., Nickels, J. S., King, J. D., Bobbie R. J. (1979). Determination of the sedimentary microbial biomass by extractable lipid phosphate. Oecologia (Berl.) 40: 51-62

Wood, B. J. B. (1974). Fatty acids and saponifiable lipids. In: Stewart, W. D. P. (ed.) Algal physiology and biochemistry University of California Press, Berkeley, p. 236-265

Manuscript first received: May 25, 1989

Revised version accepted: January 4, 1990 